\title{
1 Bronze metallurgy in the Late Phrygian settlement of 2 Gordion, Turkey
}

$3 \quad$ Frederik W. Rademakers ${ }^{1}$, Thilo Rehren ${ }^{2}$ and Mary M. Voigt ${ }^{3}$

4 Abstract

5 A detailed understanding of bronze production remains absent in most archaeological contexts, 6 despite the fundamental importance of this alloy. Here, we present a comprehensive discussion 7 of the bronze production remains from Late Phrygian/Achaemenid Gordion: crucibles, moulds 8 and casting waste, and their find contexts. A detailed microscopic analysis of crucibles is 9 complemented by chemical characterisation of their main materials (ceramic and slag), in order to discuss the technical performance of the crucibles and to evaluate the materials used for the metallurgical process. Given the lack of contemporary parallels, repeated reference is made to the Egyptian crucibles from Pi-Ramesse, for which similarly detailed descriptions are available. The crucible analyses are then connected to the other production remains, to obtain a more holistic understanding of the metallurgical process.

Finally, these technical observations are interpreted in their particular archaeological context at Gordion, and discussed from a wider perspective. The results presented here offer the first detailed overview of bronze production for ancient Phrygia, as well as the wider region. Through the inclusion of extensive online supplementary data, this paper offers a detailed technical overview of ancient (bronze) crucible analysis, of which very few examples are currently available in the wider literature.

Keywords

Phrygia, Achaemenid, bronze metallurgy, crucible analysis, moulds

${ }^{1}$ UCL Institute of Archaeology, London, United Kingdom ${ }^{1}$

+447598915857

frederik.rademakers@gmail.com

${ }^{2} U C L$ Institute of Archaeology, London, UK and College of Humanities and Social Sciences, Hamad bin Khalifa University, Doha, Qatar

+974 44578683

th.rehren@ucl.ac.uk

${ }^{3}$ College of William and Mary, Williamsburg, VA, United States of America

$+17575661510$

mmvoig@wm.edu

\footnotetext{
${ }^{1}$ Corresponding address:

KU Leuven, Division of Geology, Leuven, Belgium +3216374545

frederik.rademakers@kuleuven.be
} 


\section{Introduction}

Gordion was located on the ancient Sangarios river (modern Sakarya) in central Anatolia, near the modern town of Yassihöyük, ca. $75 \mathrm{~km}$ southwest of Ankara (Figure 1). As the capital of the Phrygian kingdom, Gordion reached its largest extent during the Middle Phrygian period, which begins ca. 800 BCE. Phrygian independence ended with subjection to Persian rule by Cyrus the Great around $540 \mathrm{BCE}$ (probably following a period of Lydian control). The period of Achaemenid rule at Gordion corresponds to the Late Phrygian archaeological period (YHSS 4 in the stratigraphic sequence for the site, ca. 540333 BCE). Under the Achaemenids, Phrygia became a satrapy with Daskyleion as its capital. Gordion remained an important economic centre and prospered: continuity in size can be seen between Middle and Late Phrygian Gordion, but many of the Middle Phrygian monumental buildings went out of use during the $6^{\text {th }}$ century. Though no longer a royal seat of power, Gordion retained much of its prestige, while escaping excessive cultural influence from the Persian rulers, attested more strongly in Lydia. By the mid- $4^{\text {th }}$ century BCE, however, Gordion appears to have lost much of its glory, and it was eventually taken by Alexander in 333 BCE. A brief historical overview of the settlement at Gordion is given by Voigt (2013), while recent changes in its stratigraphic sequence and absolute chronology (Table 1) have been summarized by Rose and Darbyshire (2011). A map of Gordion, showing the excavated areas within the central or Citadel Mound, is shown in Figure 1.

Gordion was first identified as the mound of Yassihüyük by A. Körte in 1893, based on a study of historical geography. He and his archaeologist brother Gustav subsequently excavated there and their finds confirmed the historical argument (Körte and Körte, 1904). Large scale excavations were undertaken by the University of Pennsylvania Museum under the direction of R.S. Young between 1950 and 1973. Following a period of post-excavation research led by K. DeVries, excavations started anew in 1988-2006, directed by M.M. Voigt, with G.K. Sams as Gordion Project Director. Today fieldwork and analysis continues under the direction of Brian Rose. Recent overviews of work at Gordion have been provided by Kealhofer (2005), Rose and Darbyshire (2011), Rose (2012), Voigt (2011, 2013), and the Gordion project website ${ }^{2}$.

Significant metallurgical remains at Gordion were first encountered by Young during excavations in 1953. He noted a "foundry" with slag deposits and "fragments of crucibles from which molten metal has been poured" which he dated to Hellenistic or perhaps earlier times (Young 1955:3). ${ }^{3}$ The dating of this "foundry" is not straightforward, but based on a recent analysis of ceramics and stratigraphy, the "foundry" appears to have seen only a relatively short period of use during the Late Phrygian period (late $5^{\text {th }}$ to early $4^{\text {th }}$ century BCE) and was out of use before the Hellenistic period (A. Fields personal

\footnotetext{
${ }^{2}$ Gordion Project website: http://sites.museum.upenn.edu/gordion/

${ }^{3}$ In a subsequent article Young cites the evidence from the "foundry" as "...ample evidence for a local bronzeworking industry operating as early as the middle of the seventh century" (1958:228). In fact, no direct evidence for local bronzeworking in the seventh or eighth century has ever been found at Gordion. An argument for its existence in these periods was instead based on the sheer number of typologically similar bronzes (especially fibulae) found in tombs (Young 1955:n. 6; see also 1981:247).
} 
communication 2013) ${ }^{4}$. The "foundry" structure consists of two semi-subterranean rooms with no doorway between them. The rooms were cut into deposits located above two monumental sixth century buildings and the walls were built of stone pulled from the walls of the earlier structures. The bestpreserved room measures 4.8 by 4.8 meters and the excavator describes its floor as "covered with burning and slag, pieces of crucibles, arrowheads and bronze and iron fragments". Four small pits cut into the floor were also filled with ash and slag. The second room is roughly the same size; it had a bin built of stone in one corner and a trench parallel to one wall that was "filled with [a] pure black burnt sandy substance and pieces of slag, iron clunkers etc.". Though no furnace remains were identified from the "foundry building" it appears that metallurgical activity included both bronze melting/alloying and possibly iron metallurgy. None of the crucibles discussed in this paper were directly associated with this "foundry", as the crucibles from that context were not saved for analysis, but that structure is approximately contemporary with material discussed here.

The metallurgical crucible assemblage presented in this paper was recovered during the more recent campaigns led by M.M. Voigt. The purpose of excavation in 1988-89 was to create an archaeological sequence for the site that was based on stratigraphy and the study of entire assemblages rather than architecture and a historical narrative, the foundation of Young's chronology (Voigt 2009). To obtain this sequence Voigt undertook the Yassihöyük Stratigraphic Sounding adjacent to Young's Main Excavation Area (Upper Trench Sounding, Operations 1, 2 and 7; Figure 1). The results were a new relative sequence that is keyed to absolute dates provided by Attic imports, radiocarbon and dendrochrononlogy (Table 1; Rose and Darbyshire 2011; Voigt 1994).

In this paper, crucibles from secure Late Phrygian/YHSS 4 contexts make up the majority of the assemblage. The crucibles were not excavated in obvious metallurgical contexts associated with tuyères, bellows, furnaces or other structural features. Many of the contexts are pits that were dug and used as trash deposits for metallurgical debris as well as other (domestic) trash (pottery, bones, latrine waste etc.), while other find contexts are robber trenches, ash lenses, and outside surfaces. A few crucible fragments in this sample were recovered from contexts of uncertain or Hellenistic date but these are almost certainly residual, Late Phrygian artefacts that were redeposited by pit digging. These crucibles thus all derive from 540-333 BCE contexts, but the nature of the deposits does not allow for more precise dating in most cases. More detailed contextual descriptions are provided in the online supplementary material (OSM).

In addition to the crucibles, some copper alloys and casting moulds have been identified within the same contexts (discussed in sections 3.2 and 3.3), as well as indications for iron metallurgy (probable smelting slag as well as smithing cakes, not discussed here). These deposits were strewn across an open area within Operations 1, 2 and 7, approximately 60 meters west of the presumed "foundry" excavated by

\footnotetext{
${ }^{4}$ All information on the foundry comes from the excavation of Trench NCTA3 by Jeanny Vorys Canby, Gordion NBK 39 , Gordion Archives.
} 
Young (Figure 1). It is theoretically possible that some crucibles are related to that "foundry", and were discarded at some distance from the area in which they were actually used. However, the range of evidence from the Upper Trench Sounding includes the presence of pyrotechnic features (here defined as relatively small, shallow pits with evidence for burning - reddened soil at the pit edges, ash, charcoal), along with crucible clusters and a large amount of other manufacturing debris (slag, moulds). These data suggest that a number of metallurgical workshops must have existed, most likely spread over a larger area. For a complete description of these contexts and the reconstruction of possible workshop areas, the reader is referred to the final report on the stratigraphic sounding (Voigt, in preparation).

\section{Materials and methods}

Following macroscopic description, several crucible samples were taken for detailed analysis: out of the total assemblage of 60 crucible fragments, comprising 36 rim and 24 body fragments, 46 samples were taken: 16 rim samples, 24 body samples and 6 body samples from near rims. As many of the rim fragments contain large portions of the full crucible profile, it was possible to take rim, body-near-rim as well as lower body samples from 'rim fragments'. In this way, variability of metallurgical remains within single crucibles could be assessed. A larger number of body fragments has been studied as these usually allow better reconstructions of metallurgical technology (Rademakers and Rehren, 2016). Sample selection mirrors the contextual distribution of crucible finds.

The samples were cut from the crucibles using a wet steel bench saw to obtain flat profile sections, and mounted in epoxy resin. After hardening, the mounted sections were ground using increasingly finer abrasives and polished down to $0.25 \mu \mathrm{m}$ using diamond paste.

The mounted samples were analyzed by reflected light microscopy (Leica DM4500 P LED polarization microscope) and, after carbon coating to ensure surface conductivity, by Scanning Electron Microscope (SEM: JEOL 8600 Superprobe) for structural and textural characterization of both crucible ceramic and slag. SEM-EDS (Energy Dispersive X-ray Spectroscopy) analysis (Oxford Instruments EDS attachment and INCA software) was performed to obtain quantitative chemical compositions of particular phases (point-microanalysis) and larger areas (accelerating voltage: $20 \mathrm{kV}$, working distance: $10 \mathrm{~mm}$ and live time: $50 \mathrm{~s}$ ). Bulk chemical composition was determined by averaging the analysis of five frames (magnification: 100x) for crucible ceramic and crucible slag respectively (similar to Freestone and Tite, 1986 and Martinón-Torres and Rehren, 2009; however, quartz grains and any other inclusions are included in these frames and not avoided, as their omission would bias any comparison in bulk chemical composition between different crucible parts: see Rademakers, 2015). Results are reported as

\footnotetext{
${ }^{5}$ Avoiding quartz in the analysis of the ceramic part would result in a biased (lower) silica content for the ceramic w.r.t. the slag (where quartz is included either as part of the glassy matrix or as undissolved fragments), skewing comparisons between the two. Quartz content may indeed vary from frame to frame, depending on the dominant minerals present in the analysed area. As such, a single frame may be biased w.r.t. overall ceramic composition, but averaging of multiple frames counters this
} 
normalized weight percentages of oxides. Average compositional data for ceramic and slag are presented in Table 2, while the complete dataset is discussed in full detail in the OSM. The identification of mineral phases in ceramic and slag is based on optical properties observed by reflected light microscopy, as well as chemical composition measured by SEM-EDS. This works best for opaque minerals, while identification of clay minerals is more difficult. Thin section petrography could offer more conclusive evidence, but is beyond the scope of this paper. The identification of ceramic minerals discussed in the text is mainly based on replicate SEM-EDS measurements of the same minerals across different crucible specimens (more detail in the OSM). Precision and accuracy were measured for comparable reference materials, which revealed detection limits of ca. $0.5 \mathrm{wt} \%$ for most metal (oxides). Measurement precision is generally high (coefficient of variation below 10\%), though sometimes lower for elements/oxides present at low levels and for light elements/oxides. Accuracy is similarly good, with typical relative errors of less than $10 \%$. The measurement of lead can be problematic due to polishing effects in metal phases and more generally due to the high-energy characteristic spectrum, resulting in a higher detection limit (ca. $1 \mathrm{wt} \%$ ). More details on precision/accuracy are provided in the OSM. Finally, five samples of corroded metal spills and objects were analysed. These were mounted in resin, ground and polished (procedure as outlined for crucibles), and analysed by optical microscopy and SEM-EDS. Compositional results presented throughout the text (in \%) refer to weight percentages, unless otherwise noted.

\section{Results}

\subsection{Crucible remains}

This section presents a summary of the crucible analysis by optical microscopy and SEM-EDS. As very few publications have hitherto offered a comprehensive overview of the various micro-structures and phases occurring in ancient metallurgical crucibles -often for practical reasons- this paper's OSM includes extensive details and images of the results discussed here as a reference for future crucible studies. Here, the most relevant results with respect to understanding the crucible technology are highlighted.

effect. Here, quartz fragments are relatively well distributed and smaller than the analysis frame, resulting in stable measurements of silica content for the crucible ceramic. This is apparent from the low variation in silica measured for each crucible (cfr. standard deviations and value ranges reported for silica in section 3.2 of the OSM: typically $\sigma_{\square \square \square} \approx 2 \%$ ), and across the crucible assemblage (Figure 7). 
162

163

164

165

166

167

168

169

170

171

172

173

174

175

176

177

178

179

180

181

182

183

184

185

186

187

188

189

190

191

192

193

194

195

196

No complete crucible has been found at Gordion. The largest surviving fragment, shown in Figure 2 (left), indicates a crucible height of ca. $10 \mathrm{~cm}$ (ca. $2 \mathrm{~cm}$ wall thickness, internal height $\mathrm{ca} .8 \mathrm{~cm}$ ) and a diameter of $15-18 \mathrm{~cm}$. Its horizontal cross-section is circular to elliptical. Most other fragments are smaller, usually around $5 \mathrm{~cm}$ in size. Wall thickness averages around $1.5-2 \mathrm{~cm}$, sometimes tapering to 1 $\mathrm{cm}$ at the crucible rim. These fragments do not provide much information on the complete shape of the crucibles, and no spout fragments have been encountered. They all conform to the shape deduced from the largest fragment, but might equally be fragments of smaller or larger crucibles. The average size is: diameter ca. 10-15 cm, volume ca. 270-700 ml. Reconstruction drawings are shown in Figure 2 (right). There are some indications for the use of organic temper in the fabric (see Figure 3): fibre-like impressions are visible on several exterior crucible surfaces. As these impressions do not continue deep into the crucible wall, they are best interpreted as temper burnt from the surface, rather than fracturing upon firing. Elongated porosity observed in cross section may similarly be due to burnt-out temper, though tensile fracturing due to thermal expansion and subsequent cooling of clay minerals may equally be responsible for such fractures. Differentiation of pore forming mechanisms was not possible with the methods used here, which were selected for metallurgical (slag) analysis. The (probable) organic tempering of crucibles is not consistently observed, but occurs irregularly across the assemblage.

The irregular rims, changing size, variable wall thickness and uneven exterior wall surface indicate that these crucibles were manually shaped, probably in an ad hoc rather than standardised manner.

All crucibles were heated from the inside, as can be deduced from their wall profile: from (oxidisingly) fired ceramic on the outside, to bloated, slagged ceramic on the inside. The regularity by which the crucibles are fired overall, disregarding bloated and slagged areas, suggests pre-firing before use (similar to the Pi-Ramesse crucibles: Rademakers et al., in press). The internally slagged surface is typically dark grey to black in colour, and often contains abundant green corrosion products (Figure 3), indicative of copper-related metallurgy.

Microscopic investigation confirms that, typically, three main parts are present in each section through a crucible wall:

1. On the outside, a fired ceramic zone.

2. In the centre, towards the interior surface, a porous, bloated zone which marks the disintegration of the ceramic and the transition into a slagged zone.

3. A slag zone, consisting of (almost) entirely vitrified ceramic and varying quantities of charge contributions, such as fuel ash and metal oxides.

Internal heating has caused the ceramic part to gradually become more porous towards the inside of the crucible wall, up to the point where it loses all its structurally bound water, disintegrates and bloats. The inside of the crucible shows the continuation of this bloated zone, which is a (partly) vitrified zone resulting from the complete disintegration of the ceramic, fluxed by fuel ash. Closer towards the crucible 
interior, this vitrified ceramic interacts with the crucible charge to form crucible slag. Important to note here is that this slag zone is not always well developed, resulting in a very thin or absent slag layer in a quarter of all crucible samples.

In $30 \%$ of the crucible samples, an additional interior 'layer' exists, deposited on top of the slag, consisting primarily of copper and bronze metal, their oxides and corrosion products. The limited contribution of vitrified ceramic distinguishes this layer from the crucible slag, and 'dross' is a more appropriate term for it. This dross layer is difficult to see macroscopically, but can be noted as green areas embedded in the more glassy slag zone, sometimes with fibrous or powdery corrosion on the surface.

Metallic prills were noted in three quarters of all samples. Examples of the three to four main zones typically present in each crucible profile are shown in Figure 4.

\subsubsection{Ceramic fabric}

The ceramic has medium porosity, with pore shapes that appear mainly due to expansion and shrinkage of the clay minerals and coarse inclusions upon firing. Some elongated pore shapes may indicate burntout organic temper, though such porosity does not occur in all fragments and its interpretation is often ambiguous. No phytoliths (microscopic siliceous plant secretions characteristic to plant species) were encountered.

The ceramic part is made up of a fine clay-loam fraction, with abundant small to medium angular quartz fragments and variably abundant medium to coarse (average $\varnothing=$ ca. $0.5-1.5 \mathrm{~mm}$, sometimes fragmented to $0.1 \mathrm{~mm}$ ) rock inclusions, sub-rounded to sub-angular in shape, occurring in all samples (with three exceptions, discussed below). These inclusions (Figure 5) typically consist of three main mineral phases: pyroxene (ca. 70\% diopside, 30\% hedenbergite composition), plagioclase (approximate labradorite composition: $60 \%$ anorthite, $40 \%$ albite) and spinel (65\% ulvöspinel, 35\% magnetite composition). Pyroxene and plagioclase make up the bulk of the inclusions, as more elongated crystals, while spinel is present in smaller quantities, with a characteristic isometric shape.

Diopside and hedenbergite occur in metamorphic rocks, but are equally formed during igneous crystallisation. In gabbros and basalts, labradorite is the common feldspar. Ulvöspinel-magnetite is sometimes associated with metamorphic rocks, but often crystallises from mafic (basalt-gabbro) magmas. Therefore, these inclusions are most likely mafic (basalt-gabbro) rock fragments. Based on chemical composition and following the system proposed by Le Bas et al. (1986), these rock fragments may be identified as 'normal basalt'. While these fragments could have been deliberately added to the clay as temper, they were more likely present as residual fragments in a clay weathered from basaltgabbro rock: the bulk composition of these coarse inclusions is very similar to that of the ceramic as a whole (Table 2), which has slightly lower $\mathrm{Na}_{2} \mathrm{O}$ and $\mathrm{Al}_{2} \mathrm{O}_{3}$ content and slightly higher $\mathrm{FeO}$ content (in agreement with basalt weathering observations by Colman (1982) and Eggleton et al. (1987)). Smaller inclusions in the ceramic fabric include spinel (ulvöspinel-magnetite) and pyroxenes (diopside- 
hedenbergite, augite and ferrosilite-magnetite), which are probably fragments from the coarse rock inclusions discussed above. Their relatively high abundance and shape variation may point to a weathered clay that has not undergone much transport - which would result in fewer (better densitybased separation), more rounded inclusions - consistent with the geological setting of basalt clays in Gordion. However, the addition of crushed rock of near identical composition cannot be excluded. Therefore, we suggest that a clay weathered from a mafic mother rock, with some remaining rock inclusions, was used for fabricating these crucibles. The deliberate addition of such rock fragments appears less likely, but cannot be firmly excluded based on the presented data. The presence of these rock fragments, however, might have been the reason why this particular clay was selected for its purpose, as discussed in section 4.1.

Though no detailed mineralogical fabric description for (Late Phrygian) ceramics from Gordion exists (Grave et al. (2005, 2009); Henrickson (1994, 2005) and Henrickson and Blackman (1996) mention 'coarse inclusions', but not the nature of these inclusions), the discussion of regional physical geography by Marsh $(2000,2005)$ sheds further light on the clay sources available for ceramic production. Two main soil types occur around Gordion, which reflect the major rock types upon which they developed: silty marl produced more calcareous, silty and pale clays, while basalt intrusions yielded less calcareous, red basalt-derived soils. These abundant basalt-derived soils from the eastern region surrounding Gordion, which were used for agriculture and the manufacture of domestic pottery (Grave et al., 2009), were most likely used to produce the crucibles.

A comparison of the crucible compositional data (SEM-EDS) to that available for the sediments (NAA: Henrickson and Blackman, 1996) is difficult due to the use of different techniques, range of elements and expression of measurements (oxides vs. metals). However, marls and basaltic sediment may be differentiated in both datasets by looking at the ratios of $\mathrm{FeO} / \mathrm{CaO}$ (crucibles) and $\mathrm{Fe} / \mathrm{Ca}$ (sediments). This confirms the finding that the majority of crucibles conform to this basaltic composition.

Three samples match the $\mathrm{FeO} / \mathrm{CaO}$ ratio indicating marl sediment use; they also have a ceramic fabric different from the other crucibles, as shown in Figure 6. One sample was taken from Gordion-28236, which has a grey (interior) to red (exterior) colour (pointing to oxidising conditions outside of the crucible, and more reducing conditions at its interior), limited inclusions and increased porosity. This fragment shows cracks along its exterior surface, extending deep into the profile. Its fabric feels more brittle than the other crucibles (as does the Gordion-23707 fabric, below), and chemically corresponds to marl sediments, characterised by highly elevated lime content (almost 20\%) and somewhat elevated potash content. Conversely, it has lower magnesium, aluminium, titanium and iron oxide content.

Two samples were taken from the group of small fragments (Gordion-23707, possibly representing one crucible). These consist of a thin $(<5 \mathrm{~mm})$ ceramic layer and a glassy slag layer $(<10 \mathrm{~mm})$ with green corrosion products. The ceramic has a light grey colour with small $(<1 \mathrm{~mm})$ red and white (sub-)angular quartz fragments (Figure 6), reflected in higher bulk silica contents, as well as lower magnesium, 
aluminium, titanium and iron oxide content. Additionally, higher potash and lime can be noted. This may represent sand addition to the marl sediment. These crucible fragments therefore immediately stand out due to their softer, more calcareous fabric and the lack of large rock inclusions, and probably derive from one particular workshop, given the proximity of their deposition. Comparison to fabric descriptions of contemporary domestic ceramics would be interesting to further understand the ceramic recipe used in preparing these aberrant crucibles. As far as their metallurgical use is concerned, these fragments do not stand out. The changes in bulk content between ceramic and slag do not vary significantly ${ }^{6}$ from the 'normal range' seen in other crucibles (Table 2), and 'normal' metallic prills are encountered in the crucible slag (section 3.14 and OSM). One notable difference is the exceptionally high $\mathrm{CuO}$ content in the two Gordion-23707 samples (17.3 and 24\%), reflective of abundant corrosion products.

\subsubsection{Bulk chemical changes}

281

282

This section presents the major, technologically relevant bulk chemical changes observed between the outer original ceramic and the inner bloated and slagged zones. A complete breakdown of ceramic-slag changes is included as OSM, as well as an overview of the various oxide phases present in the crucible slag.

The most abundant elements $\left(\mathrm{SiO}_{2}, \mathrm{Al}_{2} \mathrm{O}_{3}, \mathrm{FeO}\right.$ and $\mathrm{CaO}$, adding up to ca. $89 \%$ of ceramic and ca. $80 \%$ of slag bulk composition) have been plotted in ternary diagrams in Figure 7, in each case ignoring all other elements (adding $\mathrm{MgO}$ to $\mathrm{CaO}$ (chemically similar) does not alter interpretations). The ceramic composition (red) is very uniform, showing tight compositional clustering. The random presence of coarse inclusions in the area of analysis (section 3.1.2) therefore does not appear to cause variation in bulk composition in the way quartz sometimes does (see, e.g., Rademakers et al. (in press) for the PiRamesse crucibles). This strengthens the hypothesis that the coarse ceramic inclusions are naturally present as residual mother rock in the clay used for making these crucibles.

The slag compositions (blue) almost completely overlap with the ceramic composition, both in $\mathrm{SiO}_{2}-$ $\mathrm{Al}_{2} \mathrm{O}_{3}-\mathrm{FeO}$ and $\mathrm{SiO}_{2}-\mathrm{Al}_{2} \mathrm{O}_{3}-\mathrm{CaO}$. Only a few samples show minor enrichment in $\mathrm{FeO}$, while there is a general small enrichment in $\mathrm{CaO}$ (Figure 8). The biggest differences are increased copper, tin and lead oxide contents. For the three crucibles with marl-derived clay, slag composition (turquoise) shows a similar relation to the corresponding ceramic composition (orange).

The frequent presence of undissolved, fractured quartz grains in the crucible slag shows that it usually did not fully liquefy. Moreover, the actual chemical compositions are more complex than these ternary diagrams suggest (for a discussion of this, see Rehren, 2000 and Hauptmann, 2007). Additionally, redox conditions during the metallurgical process did not necessarily correspond to the equilibrium conditions for which these diagrams were constructed, and temperatures were most likely not homogeneous

\footnotetext{
${ }^{6}$ Due to differences noted between Gordion-23707 and -28236, and limited (3) samples analysed of this aberrant, marl-based fabric, the average composition in Table 2 has a high standard deviation w.r.t. the general population.
} 
throughout the crucible (process), as discussed in section 4.1 and by Rademakers and Rehren (2016). Therefore, melting temperatures of $1400-1600{ }^{\circ} \mathrm{C}$, indicated by the ternary diagrams, were probably not reached, while $1100-1200{ }^{\circ} \mathrm{C}$ represents a more realistic upper temperature range.

There is no clear distinction between rim and body samples in terms of their bulk chemical ceramic-slag changes, but dross appears primarily on body fragments (see section 3.1.6). This is the result of relatively limited crucible-charge interaction, discussed in section 4.1, and contrasts with typically more slagged, less refractory crucibles, where significant rim-body discrepancies may exist (e.g., Pi-Ramesse case: Rademakers and Rehren, 2016).

\subsubsection{Metal prills in crucible slag}

Metallic prills (typically spherical, indicating liquidity during the crucible process) have been recorded in three quarters of the crucible samples. The majority of these prills are copper-based (ranging from pure copper to (leaded) bronze, incorporating variable amounts of iron), though some exceptions occur. A complete overview of all measured metallic prills is given in the OSM, with a summary presented here (examples shown in Figure 9).

The majority of embedded prills are copper alloys. Pure copper prills occur in a few crucibles, typically surrounded by various metal oxides. The majority of prills, however, are (leaded) tin bronze. Tin content in these (leaded) tin bronze prills varies from zero to $51.5 \%$, with good representation of low- to intermediate-tin (ca. 0-12\% Sn), intermediate- to high-tin (ca. 12-20\% Sn) and high-tin (over ca. 20$25 \% \mathrm{Sn}$ ) bronze. Lead content is generally quite low, varying from zero to $3.5 \%$ (often ca. $1.5 \%$ ) without any correlation to tin content. An exception occurs in Gordion-26891: a prill with $31 \% \mathrm{~Pb}$.

Prills with $>25 \%$ Sn occur in a quarter of all crucibles, with half of them having $>40 \% \mathrm{Sn}$. The highest prill tin content (51.5\%) occurs in Gordion-23797 (with 2.5\% Co; no cobalt is measured in any of the other crucibles). High tin prills occur both in reducing and oxidising (accompanied by $\mathrm{Cu} / \mathrm{Sn} / \mathrm{Fe} / \mathrm{Pb}$ oxides) crucible slag and dross environments.

The iron content in the (leaded) bronze prills typically varies from zero to $10 \%$. An exception occurs in Gordion-22626, where some small prills contain 37.5\% Fe and an elevated zinc content (no zinc is noted in other crucibles). A tiny prill of almost pure iron occurs in Gordion-27638, with $90.5 \% \mathrm{Fe}, 7.5 \% \mathrm{Cu}$ and $2 \%$ As. Nickel is noted in low $(<1 \%)$ quantities in (high-tin) bronze prills in two crucibles (Gordion25568 and $-27734(1)$ ), where $0.5-1.2$ at\% $\mathrm{Ni}$ is present in some of the $\mathrm{Cu}-\mathrm{Sn}$ oxides and silicates too. Antimony (0.5-3.5\%) occurs in bronze prills in two crucibles (Gordion-22529 and -26891), both associated with elevated $\mathrm{PbO}$ content in the bulk crucible slag and in some cases significant lead content in the prills as well.

The majority of corroded, no longer metallic prills consist of copper chloride ( $\mathrm{CuCl}$ or cuprous chloride), often occurring in corrosion/dross layers. In Gordion-23329, a $\mathrm{Cu}_{2} \mathrm{~S}$ and $\mathrm{Pb}-\mathrm{Cu}-\mathrm{Cl}$ oxide inclusion where noted. Similar Pb-Cu-Cl oxide inclusions were noted in Gordion-26891. 
In one crucible (Gordion-22529), almost pure silver prills have been measured (slightly corroded: 4$7.5 \% \mathrm{Cl}$ ), and some embedded copper prills contain 6-10\% $\mathrm{Ag}$. In the same crucible, $1.4 \mathrm{at} \% \mathrm{Ag}$ is noted in $\mathrm{Cu}-\mathrm{Pb}-\mathrm{Cl}$ oxides (oxidised/corroded prills). The crucible slag for Gordion-22529 has a $0.35 \%$ bulk increase in $\mathrm{Ag}_{2} \mathrm{O}$, omitted from Table 2. In Gordion-23329, 3.4 at\% Ag occurs in a corroded prill as well, but was not measured in metallic prills.

\subsubsection{Charcoal and fuel ash contribution}

The Gordion excavations have yielded little evidence for tuyères (two small spout fragments were recorded) or furnace installations in which the crucibles were used. Their heating profile, however, indicates that they were heated from the inside, presumably under a charcoal cover. Evidence in the form of charcoal inclusions in the crucible slag is scarce, though an example occurs in Gordion-23797, associated with increased lime and magnesia content (see OSM).

Indirect evidence can be obtained from the comparison of crucible ceramic and slag (see section 3.1.3.), with specific attention to lime, alkali and $\mathrm{P}_{2} \mathrm{O}_{5}$ content, shown in Figure 10. Increases in these elements are indicative of a fuel ash contribution (Evans and Tylecote, 1967; Misra et al., 1993; Rovira, 2007; Tylecote, 1982; Wood, 2009) to the crucible slag formation. For the Gordion crucible slag, there is a good correlation between increases in lime and magnesia, phosphorus oxide, potash and silica, but not between lime and soda. It appears that lime and particularly magnesia are mostly concentrated in the glassy slag matrix, though their content strongly varies. The variation on the potash and phosphorus oxide measurement is too great to confidently suggest the same for these two components, though they are most likely concentrated in the glassy matrix too.

The average relative increase ${ }^{7}$ in potash (ca. $40 \% \Delta \mathrm{K}_{2} \mathrm{O} / \mathrm{Al}_{2} \mathrm{O}_{3}$ ) is similar to that in lime (ca. $30 \%$ $\Delta \mathrm{CaO} / \mathrm{Al}_{2} \mathrm{O}_{3}$ ). Compared to the Pi-Ramesse crucibles (Rademakers et al., in press), where the average relative increase in lime is over seven times greater than that in potash (ca. $330 \%$ and ca. $40 \%$ respectively, indicating strong fuel ash contributions to more developed slag), this is quite limited. While noteworthy, the cause of these differences cannot easily be deduced: charcoal and fuel composition can be highly variable, even within the same species of tree used, depending on which part of the tree (trunk, branch or twigs) is used and what time of year the wood is cut. Additionally, blowing conditions during firing can influence the varying enrichments of different fuel ash components. This difference can therefore not readily illuminate the fuel type, but makes little difference in terms of the technological interpretation presented here: fuel ash presents an important, though relatively low, contribution to the Gordion crucible slag formation. This supports an interpretation of open crucibles heated under a charcoal cover. This charcoal functioned both as fuel, producing heat to melt the charge, and as a reducing agent (Horne, 1982; Rehren, 1997). The analysis of charcoal from occupational debris by

${ }^{7}$ Relative increases in oxide ratios to alumina are calculated as: $\Delta \mathrm{MeO} / \mathrm{Al}_{2} \mathrm{O}_{3}=\frac{\frac{\mathrm{MeO}_{\text {slag }}}{\mathrm{Al}_{2} \mathrm{O}_{3} \text { slag }}-\frac{\mathrm{MeO}_{\text {ceramic }}}{\mathrm{Al}_{2} \mathrm{O}_{3 \text { ceramic }}}}{\frac{\mathrm{MeO}_{\text {ceramic }}}{\mathrm{Al}_{2} \mathrm{O}_{3} \text { ceramic }}}$ 
Miller (2010: 10, Table 4) reveals the predominant use of oak, pine and juniper in all periods, with slightly greater variety in wood types attested during the Late Phrygian period. These may have been used as fuel in phase YHSS4, but can only be indirectly linked to metallurgical activity.

\subsubsection{Dross}

A dross layer sometimes forms and floats on top of crucible charges during the metallurgical process through the oxidation of various metals. These are typically oxides of iron or other copper contaminants, as well as tin and/or lead, the main copper alloy constituents which all oxidise preferentially to copper, and some copper oxide. During casting, dross may be actively removed by the metallurgist, but is often deposited on top of the interior crucible slag. Such a layer therefore does not necessarily cover the entire crucible interior surface, but a rather small area (typically towards the crucible bottom). It is therefore not to be expected on every sherd and could be missed during sampling. Dross has been noted for nearly half of the examined crucible samples, though mainly on body fragments: ca. two thirds of the body fragment samples exhibit these dross layers, as opposed to less than one third of the rim fragment samples. It is therefore likely (though not necessary) that nearly all crucibles formed such a dross layer, which is represented in only half of the examined body samples as a result of its limited extent and random sampling.

A comparison between the average crucible ceramic, slag and $\operatorname{dross}^{8}$ composition is given in Table 2 .

Clearly, this dross is distinct from the crucible slag: it is dominated by copper, tin and lead oxide, and sometimes metallic copper. The ceramic contribution is low, as indicated by the limited alumina and silica content. Calculating the ratios of oxides to alumina (data not presented here), shows that $\mathrm{Na}_{2} \mathrm{O}$, $\mathrm{MgO}, \mathrm{SiO}_{2}, \mathrm{P}_{2} \mathrm{O}_{5}, \mathrm{~K}_{2} \mathrm{O}, \mathrm{CaO}$ and $\mathrm{TiO}_{2}$ ratios are more or less the same as those in the slag. These oxides therefore represent the crucible slag contribution to dross formation. $\mathrm{FeO} / \mathrm{Al}_{2} \mathrm{O}_{3}$, however, is three times higher for the dross than the slag (1.55 instead of 0.56). This indicates that additional iron is burnt out of the crucible charge into the dross layer, together with copper, tin and lead, due to more oxidising conditions.

\subsection{Metal remains}

A number of small corroded copper alloy fragments (amorphous lumps, many prills, a narrow strip, a nail, an unidentifiable fragment and a possible ring-like shape) were discovered in two Late Phrygian contexts, out of which three metal spills and two cast metal objects have been analysed. These objects, and magnified images of their micro-textures, are illustrated in Figure 11.

The full analytical results, as well as contextual details for these metal samples are provided in the OSM. The cast objects were (mildly) leaded tin bronzes, with approximately 6-7\% $\mathrm{Sn}$ and 1-2\% $\mathrm{Pb}$. Two of the spills have similar compositions, while the third one was probably a pure tin bronze with $10-11 \%$

\footnotetext{
${ }^{8}$ The dross layer was measured separately for five crucibles; averages here represent five times five measurements.
} 
Sn. The exact assessment of these compositions is impeded by the significant corrosion present on most samples, which consists of various copper-tin-lead oxides and chloride(-oxide)s.

One of the cast fragments (Figure 11, right) has a ring-like shape, with a rectangular corner, which roughly matches the size and shape of some of the (tentatively identified) moulds from Gordion (see section 3.3). The other large cast fragment (Figure 11, left) has a less distinct shape, and is characterised by copious amounts of high-temperature $\mathrm{SnO}_{2}$ crystals throughout its core. These indicate highly oxidising conditions at high temperature (probably during casting) where tin burns out of the bronze (see, e.g., Dungworth, 2013, Rademakers et al., in press, and Rademakers and Farci, in preparation).

Some previous analyses of copper-base material from Gordion were undertaken by Pigott et al. (1991a,b). These comprise microscopic description of (etched) metal samples and the results of their analysis by PIXE (Particle Induced X-ray Emission) analysis, which are reproduced in the OSM. There are four main alloys present: unalloyed copper, low-tin bronze (2-8\% Sn), normal (intermediate) tin bronze (10-20\% Sn) and (mildly) leaded tin bronze (3.5-16\% Sn, 1-4\% Pb). The minimal lead content for considering a sample to be either leaded bronze or 'normal' bronze is quite arbitrary here, especially since all these analyses were performed on corroded samples. Whether a strict distinction can be made between practically lead-free bronze and mildly leaded bronze is unclear on the basis of this small sample, which includes bronzes with intermediate lead contents too. Tin contents, on the other hand, show significant differentiation between low- and high-tin bronze - which do not visibly correlate to lead content. In two samples, Pigott et al. (1991 a,b) note tin contents of ca. 20\%. Though this is possible, the heavy corrosion and elevated presence of $\mathrm{SnO}_{2}$ inclusions probably causes an over-estimation of the actual tin content. In these and other samples, Pigott et al. (1991a,b) have identified $\mathrm{SnO}_{2}$ laths, which they relate to the intentional alloying of copper with cassiterite mineral in a crucible cementation process. Given that these crystals are described as laths, and these samples are spills or casts, it appears most likely that these $\mathrm{SnO}_{2}$ crystals point to oxidising casting conditions where tin was burnt out of the bronze, rather than a cementation process where different $\mathrm{SnO}_{2}$ shapes may be expected (Rademakers and Farci, in preparation). This interpretation is furthermore supported by crucible slag analysis (section 4.1) and analysis of similar metal spills presented here (high-temperature $\mathrm{SnO}_{2}$ crystals in casting spills shown in the OSM).

The overall impression from these analyses is that two alloy types were being produced and cast at Gordion: pure tin bronzes and (mildly) leaded tin bronzes. The pure tin bronzes, which sometimes have minor lead content, can be further subdivided in low and high tin bronzes. The (fairly) good separation between these different alloys may indicate that they were intentionally selected for specific purposes and perhaps subjected to different processes (casting, with or without cold working or annealing), or that alloy preference changed through time. However, the sample size presented here is far too small to assess these questions and relate alloy selection to intended object use with any true confidence; they may represent examples of a "continuous alloy spectrum", particularly with regards to lead content. 
441

442

443

444

445

446

447

448

449

450

451

452

453

454

455

456

457

458

459

460

461

462

463

464

465

466

467

468

469

470

471

472

Some ceramic fragments from the same find contexts as the casting spills discussed above appear to be mould fragments. Given the typical fragility of moulds, they are not a common archaeological find. Their contextual association to both crucible and metal remains is therefore an exciting opportunity to reconstruct casting activities at Gordion in more detail. Two examples are shown in Figure 12, while the complete set of moulds is illustrated in the OSM.

The fabric for these moulds is similar to that of the Gordion crucibles, based on macroscopic inspection. The interior surface of the moulds, however, appears to be more fine-grained and smooth, without visible coarse inclusions. This is typical for lost-wax moulds, where a fine clay is applied to the wax model, on top of which one or more coarser layers may be applied to provide mechanical stability (e.g., Craddock, 2015; Davey, 2009; Goren, 2008). The extent to which this was common practice in Phrygia or the Achaemenid Empire is difficult to assess, given the lack of comparable evidence. Prior to casting, moulds must be heated to melt and evacuate all the wax, thereby leaving a negative structure intact. The temperature profile throughout the moulds confirms that they were probably pre-fired (similar to the crucibles). Their internal grey surface is typical for clay moulds (Bayley et al., 2001, p. 16-17), and the result of exposure to higher temperatures under reducing conditions due to the contact of the interior surface with liquid metal, as it was poured into the mould and left to cool there. Contrary to the crucibles, however, no significant slag or dross formation can be noted. Though liquid metal would have entered the moulds at approximately the same temperatures as those within the hot crucibles, these temperatures were not sustained in the moulds. The internal temperature would have quickly decreased when the metal was left to cool, in contrast to the prolonged internal heating of the crucibles and the fluxing effect of the fuel ash, explaining the difference in slag formation. Therefore, the ceramic remained structurally intact during casting, but was then broken to remove the cast objects. Their similarity in ceramic fabric and firing conditions suggests that these moulds were prepared together with the crucibles. This (likely) pre-firing (not always thoroughly performed for ancient moulds) may have been significant towards their archaeological preservation.

Moulds are usually broken to recover the metal, which hinders straightforward interpretation of the shape of objects cast. The different shapes attested in this small assemblage are indicative of a variety of objects being cast at Gordion, ranging from small ring-like shapes to more elongated, rod-like (?) shapes and perhaps vessels. One example furthermore indicates that in some cases an existing ceramic vessel or shape may have been used as a mould, with the application of a coarser clay (similar to crucible fabric) to the exterior, though no distinctive traces are present on this fragment to validate its metallurgical function (OSM). 
Qualitative analysis of the exterior and interior surface by handheld X-ray fluorescence spectrometry ${ }^{9}$ indicated a significant increase in lead on the interior surface of the moulds, as well as a minor increase in copper (Figure 12). Crucibles, on the other hand, showed increased tin content on their interior surfaces, in addition to more significant copper increases. This does not contradict a relation between the crucibles and moulds, but is in line with the expectations for mould surface enrichments, as discussed by Kearns et al. (2010): for (leaded) bronzes, minor lead in the alloy is very strongly enriched in the mould, while only minor copper and very minor tin enrichments can be detected. This skewed enrichment prevents further evaluation of the relation between alloy selection and object typology.

\section{Discussion}

This discussion focuses first (section 4.1) on the technological reconstruction of the metallurgical process on the basis of results presented in section 3. This is then interpreted within the broader archaeological context of Gordion (section 4.2) and Phrygia more widely (section 4.3).

\subsection{Technical discussion}

\section{Crucible performance}

The use of a mafic rock-derived clay (section 3.1.2) has some important consequences for the crucibles' behaviour. While relatively thick crucible slag is often developed in internally heated crucibles, this is not the case in many Gordion crucibles. Typically, the thickness of the slag layer is quite modest, with a more limited bloated zone and less true vitrification than seen in, for example, the Pi-Ramesse crucibles which are of a similar design and comparable use, though with a different fabric. In many Gordion crucibles, (large parts of) the interior surfaces are merely burnt, without slag formation occurring (e.g., variable slagging on fragment in Figure 2). This slag variability in Gordion crucibles, assessed by taking multiple samples in a single crucible, is discussed in detail by Rademakers and Rehren (2016).

Several factors influence the development of crucible slag, one of the most important being the ceramic fabric. More refractory ceramics tend to react less with the crucible charge and remain both chemically and mechanically stable. The chemical composition of the Gordion crucibles is close to that of basalt. Though no (experimental) data is available to specify the clay's melting temperature, it should approximate that of dry basalts $\left(>1000{ }^{\circ} \mathrm{C}\right.$ : Bowen, 1915; Bucher and Grapes, 2011) which equals or exceeds temperatures typically attained during ancient copper or bronze melting $\left(1000-1200{ }^{\circ} \mathrm{C}\right)$. This

\footnotetext{
${ }^{9}$ The pXRF analysis of these moulds took place in 2012 at the University of Pennsylvania Museum of Archaeology and Anthropology as a means of sorting through the assemblage for sample selection. This data was obtained using their recently acquired handheld XRF (HH-XRF) device (Bruker Tracer III SD, S/N: T3S165q, yellow filter11, 45 seconds live-time), which had not been calibrated for quantitative analysis. Raw spectra were visually inspected to look at presence/absence of elements, in order to assess variability in the assemblage.
} 
means that the Gordion crucibles were operating just below or at their thermal stability (household vessels of the Late Phrygian period were fired at temperatures between 600 and $900{ }^{\circ} \mathrm{C}$; Henrickson 1993: Table 2), and therefore did not disintegrate extensively. As a result, none of the Gordion crucibles is bloated or slagged throughout their full wall profile. Crucible wall thickness is similar to or slightly lower than that of Pi-Ramesse crucibles, which is another indication that (presuming similar temperature gradients) the Gordion crucibles have better refractory performance. This performance can be partly attributed to their bulk chemistry, but is further influenced by the presence of voids induced by (perhaps limited) burnt organic temper and around coarse rock fragments. This porosity of the crucible ceramic, achieved during pre-heating, reduces fracture propagation and improves thermal insulation (Hein et al., 2013), while residual rock fragments improve toughness (Müller et al., 2010). During the metallurgical process, these fragments remain fairly stable throughout the bloated zone and in less developed slag layers. However, in more developed slag areas, the rock fragments melt and plagioclase re-crystallises into finer, more elongated shapes, often resulting in a plagioclase-dominated slag with glassy background.

It has been tentatively suggested that these rock fragments are residual to the clay, rather than intentionally added. Petrographic analysis of a variety of Gordion ceramics, allowing a comparison of crucible fabrics to contemporary ceramics, could indicate the extent to which this fragment-rich clay was selected specifically (rather than fragment-poor clay) for the purpose of crucible making, or commonly used in other domestic vessels. The macroscopically observable similarity of the crucible and mould fabrics excludes coarse fragments, which suggests a conscious differentiation for crucible and mould fabrics by the Gordion craftspeople. This could either entail variable raw clay selection (natural variation in basaltic clay around Gordion) or clay treatment (e.g., filtering out coarse fragments of the same clay for mould production). Here too, however, further microscopic analysis of the moulds is needed to bolster this argument.

When crucible disintegration is limited, so is the possibility of interaction between the crucible and its charge. Overall, this interaction (which would result in increased fuel ash, iron, copper, tin and lead content at the vitrified crucible-charge interface: the formation of slag) is relatively limited in the Gordion crucibles, though not absent. Rather, a dross layer formed in many (if not all) Gordion crucibles, in which iron, copper, tin and lead oxides are more strongly concentrated than in the actual crucible slag. Therefore, sufficient attention should be given to these dross layers to fully appreciate the metallurgical process.

An unfortunate characteristic of such dross, however, appears to be its increased sensitivity to corrosion. While crucible slag is a glassy product, effectively protecting encapsulated metallic phases, dross is dominated by metal (oxides) with only limited glassy phase present, and therefore corrodes more readily. Though metallic content is sometimes noted in this dross layer during microscopic inspection (including 
high-tin prills), it appears mostly corroded post-depositionally as illustrated by the prevalent green corrosion products (Figure 3).

541 The charcoal and fuel ash evidence (section 3.1.5) indicates that the crucibles were heated from above

542 with a tuyère (likely more than one) blowing into the crucible under a charcoal cover. The exact set-up

543 at Gordion is unknown, however. The number of tuyères, the angle at which they blew air into the

544 crucibles, the type of bellows and the shape of the furnace cannot be reconstructed. Perhaps, a bowl-

545 type furnace (e.g., Timberlake, 1994) or simple depression in the ground was used, where the crucibles

546 may have sat on a bed of sand or (non-burning) charcoal. Alternatively, more permanent structures may

547 have been present in the so-called "foundry" or hitherto undiscovered workshops. Excavations have

548 hitherto not yielded any conclusive evidence towards understanding internal workshop organization

549 (site-wide patterns are discussed in section 4.2). The crucibles themselves do not offer any further clues,

550 apart from the fact that the heat was concentrated at the crucibles' interior, while their exterior surface

551 was exposed to far lower temperatures.

\section{Metallurgical process}

553 High-tin prills (defined as those with dominant $\delta$-, $\varepsilon$ - and/or $\eta$-phase) give direct evidence for the 554 alloying of copper (or recycled bronze) with fresh tin (or cassiterite) (Crew and Rehren, 2002; 555 Rademakers et al., in press; Rehren, 2001). Re-melting of existing bronze can only result in prills with 556 a tin content equal to or below that of the recycled bronze, as tin oxidises preferentially to copper, 557 thereby lowering the tin content in trapped prills (Dungworth, 2000; Kearns et al., 2010). When alloying 558 copper (or recycled bronze) with a fresh source of tin, however, any composition intermediate between 559 pure copper and tin could be frozen in a prill. Prills of such intermediate composition can therefore be 560 taken as strong evidence for the use of a tin-rich material and indicate an active alloying process.

561 This reasoning is based on the premise that no circulating bronzes at that time had such high tin contents, 562 and these high-tin prills can therefore not represent recycling. An overview of contemporary, regional 563 bronzes (section 4.3) and newly analysed bronze spills from Gordion (section 3.2) indicates that typical 564 bronzes did not have tin contents exceeding ca. 15\%, making this a reasonable assumption. The best 565 explanation for high-tin prills, then, is that they result from the addition of a high-tin additive to the 566 crucible, most likely pure tin.

567 Such high-tin prills should be seen as an intermediate product of the alloying process and their trapping 568 in the crucible slag incidental. Thus, their absence in a particular sample cannot be interpreted as 569 counter-evidence for active alloying (as these prills are only present when full reaction did not occur in 570 the sampled crucible area).

571 Fragments in which low tin bronze prills, pure copper prills or no metallic prills occur, can therefore 572 belong to a crucible that was used for re-melting or recycling bronze, but may equally have been used 573 for active alloying. Only when high-tin prills are absent in a large sample of an investigated crucible 
assemblage can recycling practices be recognised with some confidence (Rademakers and Rehren, 2016). As outlined in section 3.1.4, bronze prills with $>25 \%$ Sn are found in about a quarter of all crucibles, while one in eight crucibles have prills with $40 \% \mathrm{Sn}$. Therefore, there is abundant evidence to suggest that active tin alloying took place at Gordion.

Interestingly, the detection frequency of high-tin prills is significantly higher than in Pi-Ramesse, where similar sample numbers were examined. This could be a sampling artefact, but might point to a higher importance of active alloying at Gordion and lower prevalence of recycling (important in Pi-Ramesse: Rademakers et al., under review), though such arguments in absentia are always tentative (Rademakers and Rehren, 2016).

Lead occurs in metallic prills in ten of the Gordion crucibles (and more often in surrounding corrosion products). Therefore, the possibility of active lead alloying should be considered. Following an argument similar to that for tin alloying, it could be expected that prills with lead levels greatly exceeding those of common leaded bronzes are indicative of an active alloying process. High-lead prills $(>30 \% \mathrm{~Pb})$, containing antimony (and arsenic), have only been encountered in one crucible (Gordion-26891), which contained several copper-lead oxides and chlorides. Interestingly, these prills show only low tin contents. (It should be kept in mind that lead content is somewhat underestimated here, particularly in metal prills (section 2).)

While the refractory character of the Gordion crucibles could impede the inclusion of lead into the crucible slag, the limited occurrence of high or even slightly elevated lead contents in bronze prills, as well as the more limited bulk slag content (bulk $\mathrm{PbO} / \mathrm{SnO}_{2}=$ ca. $0-0.5$ ), seems to indicate that lead was probably not added separately to the crucible charge and came in with another charge constituent.

The exceptional high lead prills in Gordion-26891 are surrounded by tin oxide and characterised by low tin content (Figure 13). The shape of the tin oxide suggests that it has been burnt out from the bronze. Indeed, tin is expected to oxidise more readily than lead (Ellingham, 1944), which mostly remains in the metal prill until all tin is burnt off. The high lead content of the glassy background here (ca. 19\% $\mathrm{PbO}$ ), however, illustrates the typical non-equilibrium oxidizing conditions in such small crucible areas. This tiny high lead prill therefore does not clearly illuminate the source of lead in the crucibles: either more or less pure lead or lead bearing copper/bronze. It is either an extremely skewed representation of the lead seen in other crucibles, or an outlier for the assemblage (note that this is the only crucible where significant antimony occurs repeatedly in metal prills (with the exception of the crucible associated with silver, see section 3.1.4), which could be related to a particular lead source). Given the evidence from other crucibles, it seems most likely that leaded copper was added to some crucibles, including this one. However, the lead content witnessed in this prill is not necessarily representative of the lead content of such leaded copper.

Taking into account both the evidence from crucible analysis and metal analysis, it can be reasonably assumed that predominantly pure tin bronze was produced alongside some leaded tin bronze at Gordion 
(and perhaps occasional unalloyed copper processing). Most likely, lead was not introduced separately into the crucible, but as leaded copper. This would have produced a noticeable effect on the bronze's casting properties, arguing for an intentional selection of lead-rich copper in part of the assemblage. The absence of high levels of other copper contaminants (e.g., iron) accompanying this lead lower the possibility that it was accidentally present as a contaminant following the smelting process, though low levels (below ca. 1\%) of lead in some objects (section 3.2) may represent such unintentional contaminants. While (low) iron contamination occurs in numerous prills trapped in the crucible slag, these are generally not correlated to elevated lead contents. Overall, there appears to have been a continuous range of lead contents, present in both fresh and recycled copper sources used at Gordionthe degree to which this was specifically selected for probably varied.

\section{Material use}

High tin prills indicate the practice of active alloying at Gordion, but do not illuminate the source of tin, which could either be tin metal or ore (cassiterite), to be used in a metal mixing or cementation process respectively (excluding the possibility of co-smelting). Though tin could have been introduced into crucibles as a component of recycled bronze (scrap), this explanation only suffices for crucibles where no high-tin prills are encountered: when high-tin prills are present, a fresh source of tin is implied.

$\mathrm{SnO}_{2}$ occurs in a variety of shapes (blocky to elongated/acicular), indicative of its high-temperature crystallisation in the slag, and often in large clusters associated with copper (sometimes incorporated in the metal grains: see OSM). These crystals, abundant in both the Gordion crucible slag and dross, do not provide any information on the nature of the alloying process, as they can form during (re-)melting as well as alloying operations (Rademakers and Farci, in preparation). Therefore, the only evidence to distinguish between pure metal alloying and the cementation process can be found in remnant cassiterite grains, embedded in the crucible slag (Erb-Satullo et al., 2015; Renzi and Rovira 2016: 155-59; Rademakers et al., in press).

The evidence for cassiterite use is far from compelling in the Gordion crucibles. The only (somewhat) convincing examples occur in Gordion-25394, shown in Figure 14. Here, the few possible cassiterite clusters are located in the deeper crucible slag, while the overlying dross layer is dominated by newly formed tin oxide crystals. All other clusters witnessed in the crucible slag are either too tiny to confidently build a case for cementation, or are clusters of high-temperature $\mathrm{SnO}_{2}$ crystals. Though it is possible that clusters of such crystals (more examples in OSM) represent re-crystallised mineral cassiterite grains, their common association with iron and more importantly copper oxides is indicative of a different process: they are probably the result of complete oxidation/burning of a bronze prill in that particular area, whereby all tin is converted into $\mathrm{SnO}_{2}$ crystals, iron is burnt into spinel (often incorporating some tin) and finally copper is turned into cuprite.

In conclusion, then, it appears that there is very little direct evidence at Gordion for the use of cassiterite in a cementation process. However, the absence of residual mineral grains, which are intermediate 
products, cannot conclusively argue against cassiterite cementation here. Furthermore, the use of more refractory crucibles which form a less developed slag could work against the trapping of such grains. The consequential development of a dross layer (section 3.1.6) which floats at the top of the crucible charge might further prohibit the preservation of mineral grains: the dross layers are dominated by hightemperature oxide products, due to their exposure to more oxidising conditions $\left(\mathrm{CuO}\right.$ and $\mathrm{SnO}_{2}$ make up $2 / 3$ of the bulk content). Such an environment is in stark contrast to the 'desired' setting for preservation of residual mineral grains (reducing areas, cut off from further participation in the alloying process). Conversely, the relatively abundant preservation of high-tin prills, noted above, may reasonably raise expectations of finding residual cassiterite here if cementation had been performed in the majority of crucibles. Overall, metallic tin thus appears the most likely alloy ingredient, but cassiterite may have been added to (some of) the crucible charges. Indications exist for variation in the copper used in these crucibles. As discussed in section 3.1.3, 83\% of the examined samples show no significant slag iron enrichment (average $1.6 \% \Delta \mathrm{FeO} / \mathrm{Al}_{2} \mathrm{O}_{3}$ ). The crucible slag in $17 \%$ of the samples (most of which are body fragments), however, is further enriched in iron (30-80\% $\left.\Delta \mathrm{FeO} / \mathrm{Al}_{2} \mathrm{O}_{3}\right)$. This includes two samples (Gordion-23045-S and -27609-S) taken from (exceptionally) thick crucible slag. Though this enrichment is only minor in absolute terms ${ }^{10}$, it differs significantly from the normal population and therefore merits some further attention.

663 Bulk iron enrichment roughly coincides with the appearance of iron-rich oxide phases: spinel is found in 33\% of all samples, including seven out of eight significantly iron enriched samples (and the most highly enriched samples from the 'normal population'). Spinel is typically associated with iron rich (ca. $0.5-4 \% \mathrm{Fe}$ ) copper/bronze prills (examples in OSM) implying (incompletely refined) copper as the source from which iron oxidises into the crucible slag.

The possibility of minor iron being introduced with the tin source cannot be entirely excluded: either co-reduced with cassiterite (Miller and Hall, 2008) or introduced as 'hard head' with metallic tin (Chirikure et al., 2010; Crew and Rehren, 2002; Miller and Hall, 2008; Tylecote et al., 1989). The limited iron content in tin and limited tin content in bronze, however, identify copper as the major contributor of iron.

673 As discussed above, the limited slagging of these crucibles provides little opportunity for iron to be 674 exchanged between the charge and the crucible slag. However, the similarity in $\mathrm{CuO}$ and $\mathrm{SnO}_{2}$ enrichment (around 4-5\%) seen in both Gordion and Pi-Ramesse assemblages and the general resemblance between these crucibles suggests similar operating conditions for both. Thus, the more limited slag iron enrichment very likely reflects low iron contents in the copper charged in the Gordion

679 The dross layer, however, which forms on top of the charge, is three times more enriched in iron (section 680 3.1.6). Therefore, any iron burnt out of the crucible charge is expected to be less reflected in the crucible

\footnotetext{
${ }^{10}$ This is especially true compared to that seen in Pi-Ramesse crucible slag: up to $600 \% \Delta \mathrm{FeO} / \mathrm{Al}_{2} \mathrm{O}_{3}$ ( $\mathrm{Rademakers}$ et al., in press). Similarly, lime enrichment is ca. 10 times lower in the Gordion crucibles (cfr. section 3.1.5).
} 
slag. Nonetheless, even when considering the iron enriched dross layer, the iron content of most copper used at Gordion was relatively low and more likely reflects the use of somewhat impure copper rather than raw (?) copper, even in the $17 \%$ more enriched samples.

In ca. 2/3 of examined crucible fragments, no lead enrichment is measured in the crucible slag. In the other third, bulk $\mathrm{PbO}$ enrichments up to $5 \%$ are noted (mainly body fragments). Leaded bronze prills have been noted in a quarter of the samples, of which all but two show bulk $\mathrm{PbO}$ enrichments. Therefore, leaded bronze prills are not noted in all samples exhibiting bulk $\mathrm{PbO}$ enrichment, and vice-versa, but this most likely represents a sampling artefact, introduced by crucible heterogeneity (Rademakers and Rehren, 2016). Lead generally occurs in the crucible slag either associated with copper in a particular oxide, chloride-oxide or silicate, or dissolved in the glassy slag phase (usually the case for bulk enriched samples). Very few pure lead oxides or high-lead phases were found.

As discussed earlier, lead appears to be introduced into the crucible slag with the copper. Though lead is usually found dispersed in the copper as metallic droplets, lead sulphide is occasionally encountered in association with copper (as a sulphite/sulphate in oxidising crucible conditions), suggesting its association to copper from the smelting process (not uncommon in raw ingots: e.g., Roman, 1990). In dross layers, lead often participates in the formation of various corrosion products.

Contrary to tin, which forms stable $\mathrm{SnO}_{2}$ crystals upon oxidation from bronze, lead does not seem to produce any characteristic crystals and discreetly disappears into the glassy phase, hindering its identification as a bronze oxidation product (illustrated in Figure 14, where $\mathrm{SnO}_{2}$ crystals occur in an area with localised lead-rich glassy phase).

Though the slag analysis by itself does not rule out the possibility that pure lead was added to the crucible, which then subsequently reacted with the crucible slag to form a leaded glass phase, consideration of all evidence points in the direction of lead being a component of copper introduced into several crucibles. The general impression that lead was a component in approximately half of the population (half of the body fragments) matches the observations made for Gordion metals (section 3.2): leaded bronze was one out of several alloys produced at Gordion.

Silver prills have been encountered in one crucible (Gordion-22529), and minor silver has been found in one corroded prill from another crucible (Gordion-23329). In Gordion-22529, both pure silver prills and silver-copper prills occur. The pure prills are found in the glassier crucible slag, while the mixed prills occur in the dross layer, sometimes associated with lead as well. The limited amounts of chloride associated with the silver prills are most likely due to post-depositional corrosion. The bulk $\operatorname{Ag}_{2} \mathrm{O}$ content in the slag and dross is ca. 0.3 and $0.5-0.8 \%$, respectively. The bulk $\mathrm{PbO}$ content in this crucible slag and dross is particularly high (ca. 5\%). Antimony is noted in some of the copper prills in this crucible as well.

This crucible is difficult to interpret, as several scenarios might have produced this outcome. It could have first been used for silver melting, which produced the more or less pure silver prills in the crucible 
slag, without formation of a dross layer. This would have required lower temperatures than those used for melting/alloying bronze. Following silver melting, the crucible could then have been used for bronze melting/alloying, whereby some of the silver was taken up by the copper/bronze prills. (Despite the high lead content, it is unlikely that the crucible was used for a cupellation process ${ }^{11}$, as the lead oxide content (litharge) is too low, the crucible itself does not have good cupel characteristics and it does not have an abnormal appearance compared to the rest of the assemblage.) Similarly, the crucible could have been used for bronze melting/alloying first and silver melting later. This appears unlikely, as copper/bronze residue would obviously contaminate the silver, and the silver is embedded deeper in the crucible slag than the copper/bronze. Finally, a silver-rich or -coated copper/bronze object might have been remolten in this crucible, resulting in silver-rich copper/bronze prills and pure silver prills (copper oxidises preferentially to silver). Though the presence of silver appears remarkable, the actual amount of silver is quite low and most likely points in the direction of a copper contaminant (perhaps related to its lead content). The occurrence of silver in both the crucible slag and dross furthermore indicates that it was part of a single operation involving bronze. Similarly, the high lead content in both the crucible slag and dross is most likely due to the re-melting/alloying of leaded bronze, which fits with the interpretation of the assemblage as a whole, rather than any operation particularly related to silver. A similar interpretation is appropriate for the low silver content noted in a corroded prill in Gordion-23329. It is nonetheless interesting to note that silver-bearing copper was used in one or two crucibles. This could point to a recycling operation of a silvered object or silver-bearing coinage, or a source of copper with more elevated silver content than the dominant source(s) reflected in the assemblage. It appears unlikely from this evidence that the silver content would have actually been noticed by the ancient metallurgists of Gordion.

Overall, the results indicate that significant variability existed across the assemblage in terms of copper used to produce bronze, in particular with regards to its lead content, and the tin contents aimed for in that bronze. This is in accordance with the ad hoc nature of the crucibles themselves, implying the frequent re-melting of scrap alongside the alloying of tin with (less refined) copper and possibly copper/bronze scrap.

\section{Variation in crucible slag}

746 The crucible assemblage shows variation in terms of slag composition, mineralogy and metal content, which is due to several interacting factors. These include variability in the crucible charge composition, the redox-conditions and temperature. These often change during the process and depend on the location within a crucible, which can result in varying degrees of slagging throughout a single crucible and

\footnotetext{
${ }^{11}$ In cupellation processes, a precious metal (e.g., silver) is molten with excess lead, which under oxidising conditions forms lead oxide (litharge). This litharge incorporates the base metals contaminating the precious metal, thereby purifying it (Bayley, 1996; Bayley et al., 2008).
} 
between different crucibles. The 46 samples presented here include several samples taken from the same crucible fragments to test this within-crucible variation, as well as variation across the assemblage. The results of this approach provide a stronger reliability to the interpretations offered above, and pick up general trends from the heterogeneity seen in single samples. For more details on slag variability for the Gordion assemblage and crucibles more generally, the reader is referred to Rademakers and Rehren (2016).

The potential of multiple uses or reuse of crucibles has not been mentioned yet. No obvious evidence (fused/overlying slag layers, multiple clay linings, repairs) for reuse was noted in any of the examined fragments. However, obvious evidence should not necessarily be expected, nor would microscopic evidence always reveal reuse. While it seems reasonable to suggest that the execution of two different metallurgical processes will produce a final crucible slag which cannot be reconciled with a single-use interpretation, the reuse of a crucible for the same purpose may remain quite invisible. This issue is discussed in more detail by Rademakers (2015). For the Gordion crucibles, no clear evidence for reuse exists, and the different attested processes (melting and alloying) would theoretically remain visible even if the crucibles were reused: the only difference in interpretation would be the prevalence of each process (alloying evidence "overwrites" that of simple melting), which is only assessed qualitatively anyway.

\subsection{Contextual interpretation}

The Gordion crucibles offer the first example of Phrygian crucible technology, and a detailed insight into the types of metal produced and worked within the settlement and within the context of the wider metal trade and consumption in the region. The production of crucibles at Gordion seems to have been a local affair. The metallurgists selected the most appropriate, though easily available, clay and made minor adjustments to improve its refractoriness. The crucibles were shaped by hand, suggesting a fast, ad hoc production, most probably by the metallurgists themselves. That is not to say that the crucibles were a flimsy product: their characteristics were perfectly suited to their intended technological purpose. Based on the analysis of metals and crucibles from Gordion, it appears that during the Achaemenid/Late Phrygian period, both tin bronzes and leaded tin bronzes were produced. This was done using a variety of (recycled or fresh) copper, some of which probably had a more significant lead content (naturally from the smelting process or intentionally added), together with a fresh source of tin. It is difficult to assess whether tin was added in its metallic form or as cassiterite, e.g. from the Sakarya basin (in the Phrygian hinterland) as indicated in Gale et al. (1985: Figure 2, p. 150), and the extent to which cassiterite and metallic tin would have been available through trade in this region during the Achaemenid Period is not well documented. The compositional analysis of crucible slag indicates that the copper had been fairly 'clean' (i.e., no $\mathrm{Co}, \mathrm{Ni}, \mathrm{Fe}, \ldots$ above detection limits), pointing to refined (raw or recycled) copper, while (slightly) more iron-rich copper was introduced into a small portion (ca. 17\%) of the crucibles. The presence of lead in ca. 1/3 of the crucibles may indicate the specific selection of a lead- 
rich copper source to produce leaded bronze. Recycling of existing (leaded) bronze appears to have been important too, however, while the use of fresh alloying materials, particularly tin (ore), is attested as well.

In summary, a mixture of different technological choices is reflected in the crucible assemblage. Their contextual distribution, however, does not allow any analysis to be made on whether this variable technology reflects a change in time, space or intended purpose of the produced alloy. The variability seen here might attest to an $a d$ hoc nature of the workshops (with a completely different crucible fabric attested in one workshop), where small batches of metal could have been produced with whatever metal resources available, often including scrap metal, to produce fairly small objects. However, since the crucibles were excavated in dumps rather than in situ, variability through time and between different workshops at Gordion may equally be reflected here.

Most metallurgical waste deposits are concentrated above the old (Middle Phrygian) elite quarter, not far from the citadel gate, where rather simple housing is attested during the Late Phrygian period. This pattern may indicate low intensity bronze production of independent craftspeople (Costin, 1991), in accordance with the limited technological standardization. This probably comprised various production areas (represented by pyrotechnic features) near the craftspeople's living quarters, with interspersed dump locations. Metallurgical remains found in the Northwest and Southwest Zones of the Gordion Citadel Mound are less abundant, and no pyrotechnical features dated to YHSS 4 were noted in those zones (though the excavated areas are much smaller). It may thus be argued that de-centralised, small scale melting/alloying and casting took place in the old elite quarter, while (probably more limited) bronze making in the Northwest zone may have taken place in a more controlled workshop environment. However, the available technological remains do not show any technological variability between these settings, nor do they reveal the practical organization of the workshop spaces.

One final interesting feature to note is the frequent (though not consistent) association of sand layers with the metallurgical waste deposits. This could point to the use of sand in the workshop environments, for example to provide a stable underground for either crucibles or moulds while melting and/or casting (e.g., in the "foundry"). Apart from the production of (leaded) bronze, the presence of various iron slags in these same dump contexts indicates that iron was both being smelted (primary production) and smithed (secondary process) at Gordion in the same area and period. Though discussion of iron metallurgy at Gordion is beyond the scope of this paper, it can be noted that there may have been no clear separation between bronze and iron metallurgists. Though it is hard to unequivocally prove that these were the same people, the contextual proximity indicates that they were well aware of each other's craft. 


\section{3 "Phrygian metallurgy"}

Rodney Young (1963: 357) described the Phrygians as "bronze-workers of the first order, familiar with all the techniques of casting, solid or hollow, of hammering bronze vessels by sinking or by raising, and of decorating them repoussé or by chasing", which Bilgi (2004) attributes to a deep-rooted cultural tradition. Based on the number of bronze vessels, fibulae and other items found in tumuli or elite tombs near Gordion, on distinctive aspects of metallurgical technology and form, and on a relatively early date, Young inferred that the city was the locus for production of a distinctive Phrygian style of bronze working (Young 1963: 358, 1981: 228). He takes their ready use and adaptation abroad (e.g., in Western Turkey (Lafli and Buora, 2012), the Aegean (Craddock, 1976) and Lydia) as a proxy for the dissemination of Phrygian ideas and influence. This flow of goods and ideas between Gordion and the west coast of Anatolia that began in the ninth century BCE continued into Achaemenid times when Late Phrygian Gordion was a manufacturing and trade hub.

Currently available compositional data for Phrygian(-style) objects is too limited to assess the extent to which metal objects, cast in Phrygia, were transported and used abroad, but some idea of the scale of trade during the Late Phrygian period can be gained from ceramic studies. To give one quantitative example, using the pottery from the 1988-89 stratigraphic sounding, Keith DeVries estimated that 2\% of the pottery used for food serving and consumption came from Athens. The items sent west from Gordion in exchange are not known but INAA studies now in progress may allow us to trace the exchange of ceramics within Anatolia (Grave et al., in prep).

In an effort to use style as a means of examining the exchange in metal objects, scholars have turned to what some consider the quintessential (archaeologically attested) Phrygian metal object: the fibula. Muscarella (1967) discusses the variety in Phrygian fibulae from Gordion, as well as their distribution in foreign sites (see also Young 1981:239-249). More fibulae, as well as bronze belts, are presented by Vassileva (2012). Again, sheer numbers as well as a distinctive style mark some fibula types and subtypes found in the Gordion tumuli as domestic products, with production most likely situated at Gordion during the $9^{\text {th }}-7^{\text {th }}$ century BCE, even though no moulds, slags or crucibles related to their production have been identified so far. Some information has, however, been obtained through examination of the finished Early and Middle Phrygian fibulae; this kind of study indicates that they were most likely cast in 'one-use' on some and 'multiple-use' moulds on other occasions; it appears that both open and closed moulds were used (Muscarella, 1967:48-51; Young, 1981:248-249). The moulds shown in this paper attest to a variety of objects being cast, but clear evidence for fibula production remains absent. This should not be surprising, given the near absence of Phrygian-style fibulae in Late Phrygian contexts from the 1988-89 stratigraphic sounding at Gordion, a contrast to their more common presence in deposits dated to the Early and Middle Phrygian periods (Voigt, in preparation). 
The alloys employed in the making of these various fibulae are not specified by Muscarella or Vassileva beyond the generic 'bronze' description, which could signify any copper alloy. Craddock (1978) mentions the analysis of some $8^{\text {th }}-7^{\text {th }}$ century Phrygian fibulae from Gordion (an unspecified number, but apparently those discussed by Muscarella (1967) by the Oxford Research Laboratory for Archaeology and the History of Art for Arthur Steinburg, who found they were made of brass, with "about 10\% zinc and little tin or lead" (results remain unpublished). Craddock (1978) confirmed this composition for "other Gordion fibulae" (unspecified number and details) by XRF analysis, and equally for "other Phrygian and East Greek material;" though three analysed 'Phrygian fibulae' from northern Greece are tin bronzes (Craddock, 1976). No indications for brass-working, -casting or -processing are found in the metallurgical assemblage presented in this paper. This could point to a changing preference in copper alloys through time, perhaps related to Achaemenid influence, but the possible existence of other metallurgical workshop contexts within Gordion and other Phrygian sites, hitherto undiscovered, probably go a long way in explaining this discrepancy. Eight Phrygian metal objects from $8^{\text {th }}-7^{\text {th }}$ century BCE Ankara, analysed by Atasoy and Buluç (1982), show the use of tin (ca. 10\%) bronzes, some of which were hammered and annealed. Atasoy and Buluç suggest that metal workshops outside Gordion were probably in existence, producing Phrygian-style bronzes in the $8^{\text {th }}-7^{\text {th }}$ century.

The results from metal and crucible analysis in this paper present the first analytical evidence of Phrygian (leaded) bronze production (examples from the wider Achaemenid Empire are equally unavailable). The use of this alloy during the Late Phrygian/Achaemenid period is not unusual, and is attested elsewhere in Anatolia, for example in Boğazköy during the Iron Age (Lehner, 2012). The analysis of Phrygian artefacts in particular is mentioned by Hirao et al. (1995), who note that the lead isotope compositions of most (copper) metals from Kaman-Kalehöyük, ca. 100 km SE of Gordion, appear to agree with minerals from the Ala and Bolkar Mountains (Taurus). Sayre et al. (2001) equally indicate a local origin for most (copper) metals employed within Phrygia/Anatolia, which is not surprising given the abundance of metalliferous deposits in the region. It is possible that tin was similarly acquired from within Anatolia. However, these broad observations cannot be tested for Gordion specifically without further analyses (e.g., lead and tin isotopes, as well as trace element analysis). The absence of references to (Late) Phrygian leaded bronze in the literature mainly reflects the scarcity of analyses hitherto performed. Clearly, further excavation and analysis of Phrygian metallurgical production waste is needed to shed more light on the organisation of production on a regional scale.

\section{Conclusion}

This paper has presented the Late Phrygian/YHSS 4 metallurgical remains excavated at the Gordion citadel. The analysis of the crucibles presented here is the first of its kind for Anatolian archaeology and 
beyond, and aims to serve as a reference for future studies of Phrygian metallurgy. The assemblage offers novel insights into the production of copper alloys in central Anatolia during the Achaemenid period, revealing the active alloying of bronze through the mixture of tin (either as metal or cassiterite) with copper. Several sources of copper were apparently used, probably including fresh as well as recycled copper, some of which had raised lead contents. These alloys were prepared in crucibles made of a local clay specifically selected and (probably) modified for its metallurgical function. Crucible production appears to have been ad hoc, pointing to small scale and perhaps irregular metal working represented by this assemblage; larger scale production, however, almost surely took place in Gordion, though its remains have not been recovered. Moulds of a very similar ceramic fabric to the crucibles have been found alongside limited metal spills from the crucible find contexts. These suggest an integrated production chain of the bronze objects, and offer a rare insight into Phrygian bronze casting. These findings offer a glimpse of one of the most important technologies in the ancient world, bronze making, and reveal the important variability that may occur across a seemingly homogeneous assemblage. Despite its commonness, bronze production has only rarely been studied in Iron Age Anatolia and elsewhere. Through the inclusion of detailed supplementary data, the authors aim to provide a template for future crucible studies. We hope that these results may thus engage others to study the archaeological remains of secondary metallurgy to illuminate the overall development of this often-underrated crucible technology, as well as its particular manifestations in countless ancient workshops.

\section{Acknowledgments}

Results presented in this paper are part of the first author's $\mathrm{PhD}$ research undertaken at the UCL Institute of Archaeology (Rademakers, 2015), which was funded by an ESR fellowship from the European Union: Marie Curie ITN (FP7-PEOPLE-2010) NARNIA project (grant 265010, led by V. Kassianidou). Unless otherwise noted, all analyses were undertaken at the Wolfson Archaeological Science Laboratories, UCL Institute of Archaeology. We want to thank Harriet White for her tireless support in the sample preparation lab and Kevin Reeves for his valuable help in the SEM lab. We would further like to thank Alison Fields for compiling field notes on the foundry evidence excavated by Young, and Peter Grave and Lisa Kealhofer for sharing their thoughts on the available Gordion ceramic data. Finally, the first author would like to thank Naomi Miller and the other staff at the University of Pennsylvania Museum of Archaeology and Anthropology for their hospitality during his brief research stay there in the framework of this study.

All modern archaeological research at Gordion (1950-2006) has been sponsored and supported by the University of Pennsylvania Museum; the College of William and Mary has been a co-sponsor since 1991, and the Royal Ontario Museum co-sponsored work carried out between 1994 and 2002. Excavation and survey at Gordion since 1988 has been supported by grants from the National Endowment for the Humanities (NEH, a US federal agency), the Social Science and Humanities 
Research Council of Canada, the National Geographic Society, the Royal Ontario Museum, the Kress Foundation, the IBM Foundation, the Tanberg Trust and by gifts from generous private donors.

\section{References}

Atasoy, E. and Buluç, S. (1982): Metallurgical and archaeological examination of Phrygian objects, Anatolian Studies, 32, 157-160.

Bayley, J. (1996): Innovation in later medieval urban metalworking, Historical Metallurgy, 30, 67-71.

Bayley, J., Dungworth, D., and Paynter, S. (2001): Centre for Archaeology Guidelines: Archaeometallurgy, Swindon: English Heritage Publications.

Bilgi, Ö., ed. (2004): Anatolia, Cradle of Castings, Istanbul: Döktaş.

Bowen, N.L. (1915): The later stages of the evolution of the igneous rocks, The Journal of Geology, 23, $1-91$.

Bucher, K. and Grapes, R. (2011): Petrogenesis of Metamorphic Rocks, 8th Edition, Berlin Heidelberg: Springer.

Chirikure, S., Heimann, R.B., and Killick, D. (2010): The technology of tin smelting in the Rooiberg Valley, Limpopo Province, South Africa, ca. 1650-1850 CE, Journal of Archaeological Science, 37 , 1656-1669.

Colman, S.M. (1982): Chemical Weathering of Basalts and Andesites: Evidence from Weathering Rinds, U.S. Geological Survey, Professional Paper 1246

Costin, C.L. (1991): Craft specialization: issues in defining, documenting, and explaining the organization of production, Archaeological Method and Theory, 3, 1-56.

Craddock, P.T. (1976): The composition of the copper alloys used by the Greek, Etruscan and Roman civilizations. 1: The Greeks before the Archaic Period, Journal of Archaeological Science, 3, 93-113.

Craddock, P.T. (1978): The composition of the copper alloys used by the Greek, Etruscan and Roman civilizations. 3: The origins and early use of brass, Journal of Archaeological Science, 5, 1-16.

Craddock, P.T. (2015): The metal casting traditions of South Asia: continuity and innovation, Indian Journal of History of Science, 50, 55-82.

Crew, P. and Rehren, Th. (2002): High-temperature workshop residues from Tara - iron, bronze and glass, Discovery Programme Report, 6, 83-103. 
Davey, C.J. (2009): The early history of lost-wax casting, in J. Mei and Th. Rehren, eds., Metallurgy and Civilisation. Eurasia and Beyond, London: Archetype Publications, pp. 147-154.

Dungworth, D. (2000): A note on the analysis of crucibles and moulds, Historical Metallurgy, 34, 8386.

Dungworth, D. (2013): Experimental archaeometallurgy: hypothesis testing, happy accidents and theatrical performances, in D. Dungworth and R.C.P. Doonan, eds., Accidental and Experimental Archaeometallurgy, HMS Occasional Publication 7, The Historical Metallurgy Society, pp. 11-16.

Eggleton, R.A., Foudoulis, C., and Varkevisser, D. (1987): Weathering of basalt: changes in rock chemistry and mineralogy, Clay and Clay Minerals, 35, 161-169.

Ellingham, H.J.T. (1944): Reducibility of oxides and sulphides in metallurgical processes, Journal of the Society of Chemical Industry, 5, 125-133.

Erb-Satullo, N.L., Gilmour, B.J.J., and Khakhutaishvili, N. (2015): Crucible technologies in the Late Bronze-Early Iron Age South Caucasus: copper processing, tin bronze production, and the possibility of local tin ores, Journal of Archaeological Science, 61, 260-276.

Evans, R.T. and Tylecote, R.F. (1967): Some vitrified products, Bulletin of the Historical Metallurgy Group, 1, 22-23.

Fields, A. (2011): The Late Phrygian Citadel at Gordion, Turkey: a Preliminary Study, Unpublished Master's thesis, University of Cincinnati, Department of Classics, Cincinnati, OH.

Gale, N.H., Stos-Gale, Z.A., and Gilmore, G.R. (1985): Alloy types and copper sources of Anatolian copper alloy artifacts, Anatolian Studies, 35, 143-173.

Goren, Y. (2008): The location of specialized copper production by the lost wax technique in the Chalcolithic southern Levant, Geoarchaeology, 23, 374-397.

Grave, P., Kealhofer, L., and Marsh, B. (2005): Ceramic compositional analysis and the Phrygian sanctuary at Dümrek, in L. Kealhofer, ed., The Archaeology of Midas and the Phrygians: Recent Work at Gordion, Philadelphia, PA: University of Pennsylvania Museum of Archaeology and Anthropology, pp. 149-160.

Grave, P., Kealhofer, L., Marsh, B., Sams, G.K., Voigt, M., and DeVries, K. (2009): Ceramic production and provenience at Gordion, Central Anatolia, Journal of Archaeological Science, 36, 2162 2176.

Grave, P., Kealhofer, L., Sams, G.K., and Voigt, M.M. (in preparation): Communities, Politics and Identity: Ceramic Analyses from Late Bronze and Iron Age Gordion 
Hall, F.P. and Insley, H. (1933): A compilation of phase-rule diagrams of interest to the ceramist and silicate technologist, Journal of the American Ceramic Society, 16, 463-567.

Hauptmann, A. (2007): The Archaeometallurgy of Copper - Evidence from Faynan, Jordan, Springer.

Hein, A., Karatasios, I., Müller, N.S., and Kilikoglou, V. (2013): Heat transfer properties of pyrotechnical ceramics used in ancient metallurgy, Thermochimica Acta, 573, 87-94.

Henrickson, R.C. (1993): Politics, economics, and ceramic continuity at Gordion in the late second and first millennia B.C., in W.D. Kingery, ed., Social and Cultural Contexts of New Ceramic Technologies, Ceramics and Civilization Vol. 6, Ohio: American Ceramic Society, pp. 89-176.

Henrickson, R.C. (1994): Continuity and discontinuity in the ceramic tradition at Gordion during the Iron Age, in D. French and A. Çilingiroğlu, eds., Anatolian Iron Ages 3. The Proceedings of the Third Anatolian Iron Ages Colloquium Held at Van, 6-12 August 1990, British Institute of Archaeology at Ankara, Monograph 16, London: British Institute of Archaeology at Ankara, pp. 95-129.

Henrickson, R.C. (2005): The local potter's craft at Phrygian Gordion, in L. Kealhofer, ed., The Archaeology of Midas and the Phrygians: Recent Work at Gordion, Philadelphia, PA: University of PennsylvaniaMuseum of Archaeology and Anthropology, pp. 124-135.

Henrickson, R.C. and Blackman, M.J. (1996): Large-scale production of pottery at Gordion: a comparison of the Late Bronze and Early Phrygian industries, Paléorient, 22, 67-87.

Hirao, Y., Enomoto, J., and Tachikawa, H. (1995): Lead isotope ratios of copper, zinc and lead minerals in Turkey in relation to the provenance study of artefacts, in H.I.H. Prince Takahito Mikasa, ed., Essays on Ancient Anatolia and its surrounding civilisations, Wiesbaden: Harrassowitz Verlag, pp. 89-114.

Horne, L. (1982): Fuel for the metal worker - the role of charcoal and charcoal production in ancient metallurgy, Expedition, 25, 6-13.

Kealhofer, L., ed. (2005): The Archaeology of Midas and the Phrygians: Recent Work at Gordion, Philadelphia, PA: University of Pennsylvania Museum of Archaeology and Anthropology.

Kearns, T., Martinón-Torres, M., and Rehren, Th. (2010): Metal to mould: alloy identification in experimental casting moulds using XRF, Historical Metallurgy, 44, 48-58.

Klein, C. and Dutrow, B. (2007): Manual of Mineral Science (23rd edition), Wiley.

Körte G. and A. Körte (1904): Gordion: Ergebnisse der Ausgrabung im Jahre 1900. Jahrbuch des Deutschen Archäologischen Instituts, Supplement 5. Berlin; G. Reimer. 
Lafli, E. and Buora, M. (2012): Fibulae in the Museum of Ödemis (Western Turkey), Oriental Archive, $80,1-18$.

Le Bas, M.J., Le Maitre, R.W., Streckeisen, A., and Zanettin, B. (1986): A chemical classification of volcanic rocks based on the total alkali-silica diagram, Journal of Petrology, 27, 745-750.

Lehner, J.W. (2012): A preliminary report on the microstructure and microanalysis of metal from Boğazköy, Archaologischer Anzeiger, 2011, 57-64.

Marsh, B. (2000): Geomorphology of the Gordion Regional Survey, Unpublished report dated September 12, 2000, Gordion archive, Philadelphia, PA: University of Pennsylvania Museum of Archaeology and Anthropology.

Marsh, B. (2005): Physical geography, land use, and human impact at Gordion, in L. Kealhofer, ed., The Archaeology of Midas and the Phrygians: Recent Work at Gordion, Philadelphia, PA: University of Pennsylvania Museum of Archaeology and Anthropology, pp. 161-171.

Martinón-Torres, M. and Rehren, Th. (2009): Post-medieval crucible production and distribution: a study of materials and materialities, Archaeometry, 51, 49-74.

Mellink, M.J. (1956): Archaeology in Asia Minor, American Journal of Archaeology, 60, 369-384.

Miller, N.F. (2010): Botanical Aspects of Environment and Economy at Gordion, Turkey, Philadelphia, PA: University of Pennsylvania Museum of Archaeology and Anthropology.

Miller, D. and Hall, S. (2008): Rooiberg revisited - the analysis of tin and copper smelting debris, Historical Metallurgy, 42, 23-38.

Misra, M.K., Ragland, K.W., and Baker, A.J. (1993): Wood ash composition as a function of furnace temperature, Biomass and Bioenergy, 4, 103-116.

Muan, A. (1957): Phase equilibria at liquidus temperatures in the system iron oxide- $\mathrm{Al}_{2} \mathrm{O}_{3}-\mathrm{SiO}_{2}$ in air atmosphere, Journal of the American Ceramic Society, 40, 121-133.

Müller, N.S., Kilikoglou, V., Day, P.M., and Vekinis, G. (2010): The influence of temper shape on the mechanical properties of archaeological ceramics, Journal of the European Ceramic Society, 30, $2457-2465$.

Muscarella, O.W. (1967): Phrygian Fibulae from Gordion, Colt Archaeological Institute, London and Beccles: William Clowes and Sons, Limited.

Pigott, V.C., Fleming, S.J., and Darby, C. (1991): Preliminary Research on Copper-Base Material at Gordion: Metallographic and Compositional Analyses, MASCA Archaeometallurgy Interim Report, University of Pennsylvania Museum of Archaeology and Anthropology. 
Rademakers, F.W. (2015): Into the Crucible. Methodological Approaches to Reconstructing Crucible Metallurgy, from New Kingdom Egypt to Late Roman Thrace, Unpublished PhD Thesis, University College London, URI: http://discovery.ucl.ac.uk/id/eprint/1469615

Rademakers, F.W. and Farci, C. (in preparation): Tin oxide in crucible slag: understanding ancient technological choices through experimental bronze making, Journal of Archaeological Science: Reports.

Rademakers, F.W. and Rehren, Th. (2016): Seeing the forest for the trees: Assessing technological variability in ancient metallurgical crucible assemblages, Journal of Archaeological Science: Reports, $7,588-596$

Rademakers, F.W., Rehren, Th., and Pernicka, E. (under review): Copper for the Pharao: identifying multiple metal sources for Ramesses' workshops from bronze and crucible remain, Journal of Archaeological Science

Rademakers, F.W., Rehren, Th., and Pusch, E.B. (in press): Bronze production in Pi-Ramesse: Alloying technology and material use, in E. Ben-Yosef and Y. Goren, eds., Mining for Copper: Essays in Honor of Professor Beno Rothenberg, Tel Aviv: Institute of Archaeology of Tel Aviv.

Rehren, Th. (1997): Die Rolle des Kohlenstoffs in der prähistorischen Metallurgie, Stahl und Eisen, $117,87-92$.

Rehren, Th. (2000): Rationales in Old World base glass compositions, Journal of Archaeological Science, 27, 1225-1234.

Rehren, Th. (2001): Die Schmelzgefässe aus Cham-Oberwil, in U. Gnepf Horisberger and S. Hämmerle, eds., Cham-Oberwil, Hof (Kanton Zug). Befunde und Funde aus der Glockenbecherkultur und der Bronzezeit, Basel, , pp. 118-131.

Renzi, M. and Rovira-Llorens, S. (2016): Metallurgical vessels from the Phoenician site of La Fonteta (Alicante, Spain): a typological and analytical study, in G. Körlin, M. Prange, Th. Stöllner, and Ü. Yalcin, eds, From Bright Ores to Shiny Metals, pp. 143-166

Roman, I. (1990): Copper ingots, in B. Rothenberg, ed., The Ancient Metallurgy of Copper: Archaeology-Experiment-Theory, London: The Institute for Archaeo-Metallurgical Studies, pp. 176181.

Rose, C.B., ed. (2012) The Archaeology of Phrygian Gordion, Royal City of Midas. Gordion Special Studies VII. Philadelphia, PA: University of Pennsylvania Museum of Archaeology and Anthropology

Rose, C.B. and Darbyshire, G., eds. (2011): The New Chronology of Iron Age Gordion, Philadelphia, PA: University of Pennsylvania Museum of Archaeology and Anthropology. 
Rovira, S. (2007): La producción de bronces en la prehistoria, in J. Molera, J. Farjas, P. Roura, and T. Pradell, eds., Avances En Arqueometría. Actas Del VI Congreso Ibérico De Arqueometría 2005, Girona: Universidad de Girona, pp. 21-35.

Sayre, E.V., Joel, E.C., Blackman, M.J., Yener, K.A., and Özbal, H. (2001): Stable lead isotope studies of Black Sea Anatolian ore sources and related Bronze Age and Phrygian artefacts from nearby archaeological sites. Appendix: new Central Taurus ore data, Archaeometry, 43, 77-115.

Timberlake, S. (1994): An experimental tin smelt at Flag Fen, Historical Metallurgy, 28, 121-128.

Tylecote, R.F. (1982): Metallurgical crucibles and crucible slags, in J.S. Olin and A.D. Franklin, eds., Archaeological Ceramics, Washington, D.C.: Smithsonian Institution Press, pp. 231-243.

Tylecote, R.F., Photos, E., and Earl, B. (1989): The composition of tin slags from the South-West of England, World Archaeology, 20, 434-445.

Vassileva, M. (2012): Early bronze fibulae and belts from the Gordion citadel mound, in C.B. Rose, ed., The Archaeology of Phrygian Gordion, Royal City of Midas, Philadelphia, PA: University of Pennsylvania Museum of Archaeology and Anthropology, pp. 111-126.

Voigt, M.M. (1994): Excavations at Gordion, 1988-89: The Yasslhöyük stratigraphic sequence, in D. French and A. Çilinguroğlu, eds., Proceedings of the 3rd International Anatolian Iron Age Symposium (Van, 1990), British Institute of Archaeology at Ankara Monograph 16, Oxford: Oxbow Books pp. 265293.

Voigt, M.M. (2009): The chronology of Phrygian Gordion, in S. Manning and J.J. Bruce, eds., Tree Rings, Kings and Old World Archaeology, Ithaca: Cornell University Press, pp. 319-327.

Voigt, M.M. (2011): Gordion: the changing political and economic roles of a first millennium city, in S. Steadman and G. McMahon, eds, The Oxford Handbook of Ancient Anatolia, Oxford: Oxford University Press, pp. 1069-1094.

Voigt, M.M. (2012): Human and animal sacrifice at Galatian Gordion: the uses of ritual in a multiethnic community, in A. Porter and G. Schwartz, eds., Sacred Killing: the Archaeology of Sacrifice in the Ancient Near East, Winona Lake, Indiana: Eisenbrauns, pp. 235-288.

Voigt, M.M. (2013): Gordion as city and citadel, in S. Redford and N. Ergin, eds., Cities and Citadels in Turkey: From the Iron Age to the Ottomans, Leuven: Peeters Publishing, Koç Institute Monograph, pp. 161-228.

Voigt, M.M. (in preparation): The Yassihöyük Stratigraphic Sequence. Gordion Excavation Final Reports, Philadelphia: The University of Pennsylvania Museum of Archaeology and Anthropology 
1109 Voigt, M.M. and Young, T.C.Jr. (1999): From Phrygian capital to Achaemenid entrepot: Middle and 1110 Late Phrygian Gordion, Iranica Antiqua, 34, 191-241.

1111 Wood, N. (2009): Some implications of the use of wood ash in Chinese stoneware glazes, in A.J. 1112 Shortland, I.C. Freestone, and Th. Rehren, eds., From Mine to Microscope. Advances in the Study of 1113 Ancient Technology, Oxford: Oxbow Books, pp. 51-60.

1114 Young, R.S. (1955): Gordion: Preliminary Report, 1953, American Journal of Archaeology, 59, 1-18.

1115 Young, R.S. (1958): Bronzes from Gordion's Royal Tomb, Archaeology, 11, 227-231.

1116 Young, R.S. (1963): Gordion on the Royal Road, Proceedings of the American Philosophical Society, $1117 \quad 107,348-364$.

1118 Young, R.S. (1981): Three Great Early Tumuli. The Gordion Excavations Final Reports, Vol. I, 1119 University Museum Monograph 43, Philadelphia: The University Museum, University of Pennsylvania. 